\title{
Bacterial bioaerosol concentration and size distribution in the selected animal premises in a zoological garden
}

\author{
Jacek Grzyb · Anna Lenart-Boroń (i)
}

Received: 24 June 2018/ Accepted: 19 December 2018/Published online: 3 January 2019

(C) The Author(s) 2019

\begin{abstract}
Currently, there are almost no studies concerning bioaerosol and particulate matter levels in animal enclosures of zoos. Numerous air contamination sources can be found there, and zoos are both working environments and popular tourist objects. The aim of this study was to assess bacterial aerosol levels in premises for animals (giraffes, monkeys, pheasants and ostriches) of the Kraków Zoo. Bioaerosol samples were collected using six-stage Andersen impactor to assess the concentration and size distribution of airborne mesophilic bacteria, Gram-negative bacteria and staphylococci. Particulate matter levels $\left(\mathrm{PM}_{10}, \mathrm{PM}_{4}, \mathrm{PM}_{2.5}\right.$ and $\left.\mathrm{PM}_{1}\right)$ were assessed using DustTrak Aerosol Monitor. The results showed that the concentration of airborne bacteria varied significantly between enclosures for the analyzed animal groups and various groups of bacteria reached their maximum concentrations in premises for different animals. The mean share of respirable fraction of bacteria was quite high-68\%, with values ranging from $12.8 \%$ for Gram-negative bacteria to $98 \%$ for mannitol-positive staphylococci, indicating potential harmfulness to the health of exposed people. Dust concentrations remained at similar, relatively low levels (maximum of $0.105 \mathrm{mg} / \mathrm{m}^{3}$ for $\mathrm{PM}_{10}$ in rooms for giraffes). This study showed that neither bacterial
\end{abstract}

J. Grzyb · A. Lenart-Boroń ( $₫)$

Department of Microbiology, University of Agriculture in Kraków, Mickiewicza Ave 24/28, 30-059 Kraków, Poland e-mail: anna.lenart-boron@urk.edu.pl bioaerosol levels, nor dust concentrations exceed the permissible values provided by Polish guidelines, but comparing the values with other countries' limits suggests that the air could be considered as contaminated. The animals are a significant source of bioaerosol; therefore, attention should be paid to thorough cleaning of animals themselves and their premises and to maintaining appropriate levels of microclimatic parameters prevailing in the rooms.

Keywords Bacterial aerosol - Environmental exposure $\cdot$ Health risk $\cdot$ Occupational exposure

\section{Introduction}

The history of zoos dates back to the ancient times. The world's oldest zoo, but at the same time modern and existing until today is the Tiergarten Schönbrunn in Vienna founded in 1752. The oldest Polish zoo was founded in 1865 in Wrocław. Currently, in Poland there are 23 zoological gardens, including 11 that meet the world standards (among others in Wrocław, Warszawa, Gdańsk and Kraków). The latter zoos belong to the European Association of Zoos and Aquariums, i.e., EAZA (Kruszewicz 2011; EAZA 2014). The EAZA standards, based on current knowledge and practice, force their members to care for animals (ensuring their welfare, health and hygiene), 
to provide proper veterinary care, manage reproduction and ensure safety of animals and visitors. In turn, the Animal Welfare Code provides five basic rules for dealing with animals: freedom from hunger and thirst, freedom from discomfort, freedom from disease, pain and injury, freedom from stress and ability to express normal behavior (Kołacz and Bodak 1999).

Over the last 100 years, many things have changed in zoos: the life expectancy of animals exhibited has increased significantly, medicine of exotic animals has developed, living conditions have improved, and breeding work has intensified. Zoological gardens have the greatest opportunity to save animal species threatened with extinction, which helps to preserve biodiversity and to protect genetic resources (Tombarkiewicz et al. 2008).

A zoo is a conglomerate of artificial environments created for both native and exotic animals, that provides them with the best living conditions (the so-called welfare). Welfare of animals includes properly adjusted surface and cubature, terrain, temperature and humidity. Area and volume as well as cast and size of animals affect the bioaerosol and dust concentration in animal premises (Zubkowicz 2004). The conditions that should be met by rooms for particular groups of animals are included in the Regulation of the Minister of Environment of 2004 (Journal of Laws 2004).

In animal rooms, as a result of the presence of litter, different types of feed, and-for a part of the dayalso feces of animals, the concentration of bioaerosol can be comparable to the one recorded in livestock premises. Usually, concentrations of airborne microorganisms in such premises are significantly higher than in human dwellings. Similarly, as in the case of animal production facilities, the concentration of bioaerosols, dust and odorous volatile compounds increases with increasing number of animals or the related equipment (Millner 2009). It has been well documented that the exposure to these contaminants of indoor environments is associated with a range of acute and/or chronic adverse health effects and diseases (Douwes et al. 2003; Kaliste et al. 2002; Samadi et al. 2013). The most commonly reported include respiratory system problems (e.g., rhinitis, asthma, bronchitis, sinusitis), allergic mechanisms, gastrointestinal distress, fatigue and headache (Douglas et al. 2018). In the case of zoos, the abovementioned effects mostly concern workers, i.e., zookeepers, whose task is to be responsible for feeding and daily care of animals kept in captivity. They are also expected to clean the animals, their cages and enclosed spaces where animals are kept. All these activities are related to the direct exposure to dust particles and bioaerosols originating from animal skin, feces, feed and bedding (Kaliste et al. 2002; Lorenz 2004).

Although many studies have been published on bioaerosols in various animal production or animal care settings, such as stables, farms, barns, swine houses and poultry housing (Chien et al. 2011; Douglas et al. 2018; Matković et al. 2007; Millner 2009; Zhao et al. 2014), no comprehensive microbiological analyses have been carried out in zoological gardens to assess the microbiological contamination of rooms for various species of animals. A factor hindering the verification of the results obtained is also the lack of relevant standards or studies, which the results could be directly related to. Zoos are a unique environment where animals are kept in confinement, often indoors, where all animal care activities are performed by their caretakers. Also, the specificity of these places includes visits of tourists, often with small children, whose respiratory tract is often more vulnerable to contamination because it has different proportions than the respiratory tract of adults, their activity is more diverse and intensive, they breathe more air relative to their body size than adults, and their immune systems are less mature (Yoon et al. 2011). Therefore, children are at particular risk of lung damage as a result of contact with poor air quality (D'Arcy et al. 2012).

The main aim of the study was to assess the microbial and dust contamination of air in the selected animal premises of the Kraków Zoological Garden. The specific aims included the determination and analyses of:

- the size distribution of viable bacterial aerosol and dust particles in houses of four different animal species;

- whether the total and respirable fractions of bacterial bioaerosol components differ depending on the animals tested;

- whether the observed bioaerosol concentrations may pose health risks to the visitors and workers of the zoo, particularly with respect to the respirable fraction content; 
- which factors most significantly determine the observed levels of bacterial aerosol.

The obtained results might shed light on the quality of air in animal premises of zoological gardens and the possible health risks associated with contact with microbial aerosols and dust particles in zoos.

\section{Materials and methods}

The study was conducted in a zoological garden in Kraków. It is a medium-sized zoo, with an area of 16.67 hectares, which exhibits more than 1400 animals of approx. 270 species with a numerous group of endangered animals (more than 100 species, among others red panda, snow leopard or Siberian tiger) (http://zoo-krakow.pl/). The selection of the study site was based on its convenient accessibility and proximity. The measurements were taken inside four premises where animals are kept (giraffes, monkeys, pheasants and ostriches). The selection of animals for the study was based on the assumption to examine the representatives of mammals (giraffes and monkeys) and birds (ostriches and pheasants). At the same time, the size of animals was taken into considerationsmall (monkeys and pheasants) versus large (giraffes and ostriches). Another criterion for the selection was the age of the animal houses-giraffes and ostriches were kept in new premises, while pheasants and monkeys were in older ones (Table 1). One site located outdoors, at a distance of approx. $10 \mathrm{~m}$. from one of the analyzed buildings, was treated as control. The location of the sampling sites is shown in Fig. 1, and their characteristics are given in Table 1.

The air samples were collected in the period from October 2016 to May 2017 (in three seasons: autumn, winter and spring, when the animals were present indoors) using a six-stage Andersen-Graseby model WES-710 cascade impactor (Westech Instrument, UK). The use of this device allows to distinguish the following aerodynamic diameter ranges of bioaerosol: $>7 \mu \mathrm{m}$ (stage one), 4.7-7 $\mu \mathrm{m}$ (stage two), 3.3-4.7 $\mu \mathrm{m}$ (stage three), 2.1-3.3 $\mu \mathrm{m}$ (stage four), 1.1-2.1 $\mu \mathrm{m}$ (stage five) and 0.65-1.1 $\mu \mathrm{m}$ (stage six). Samples were collected between 7.00 AM and 9.00 AM (before opening of the zoo for visitors). Each sample included six impaction stages with Petri dishes; in sum, there were 810 Petri dishes with biological material analyzed during the study. Per each season, we collected 270 samples (90 for one replicate). Between each sampling, the impactor was disinfected by using cotton balls immersed in $70 \%$ ethanol. The sampling time was $4 \mathrm{~min}$, which with the air flow through the impactor of $28.3 \mathrm{l} / \mathrm{min}$ gave the volume of aspirated air of 113.21 . The air sampler was placed at the height of $1.5 \mathrm{~m}$ above the ground level to collect the air from the human breathing zone. The following microbiological media were used to collect bioaerosol samples: trypticase soy agar (Biocorp, Poland) for the total number of mesophilic bacteria, eosin methylene blue (Biocorp, Poland) for Gramnegative bacteria and mannitol salt (Chapman) agar (Biocorp, Poland) for Staphylococcus spp. The

Table 1 Characteristics of the studied premises

\begin{tabular}{|c|c|c|c|c|}
\hline Group of animals & Giraffes & Monkeys & Pheasants & Ostriches \\
\hline Total area $\left(\mathrm{m}^{2}\right)$ & 732 & 434 & 80 & 85 \\
\hline Age/year of construction & $3 / 2013$ & $10 / 2006$ & $42 / 1974$ & New/2016 \\
\hline Number of animals & 3 & 19 & 11 & 8 \\
\hline Area per animal $\left(\mathrm{m}^{2}\right)$ & 244 & 22.8 & 7.3 & 10.6 \\
\hline Number of windows/doors & $37 / 6$ & $30 / 4$ & $11 / 2$ & $5 / 5$ \\
\hline Type of ventilation & $\begin{array}{l}\text { Mechanical with air } \\
\text { heating }\end{array}$ & $\begin{array}{l}\text { Mechanical with air } \\
\text { heating }\end{array}$ & $\begin{array}{l}\text { Gravity; } 2 \text { ducts-diameter } \\
\text { of } 150 \mathrm{~mm}\end{array}$ & $\begin{array}{l}\text { Gravity; } 4 \text { ducts- } \\
\text { diameter of } 150 \mathrm{~mm}\end{array}$ \\
\hline Frequency of air exchange & $\begin{array}{l}\text { Cold season: 4/day } \\
\text { Hot season: 6/day }\end{array}$ & $\begin{array}{l}\text { Cold season: 6/day } \\
\text { Hot season: 6/day }\end{array}$ & - & - \\
\hline Type of bedding & Sawdust beech & Shredded pine bark & Shredded pine bark + sand & $\begin{array}{l}\text { Straw from } \\
\text { triticale }+ \text { sand }\end{array}$ \\
\hline
\end{tabular}




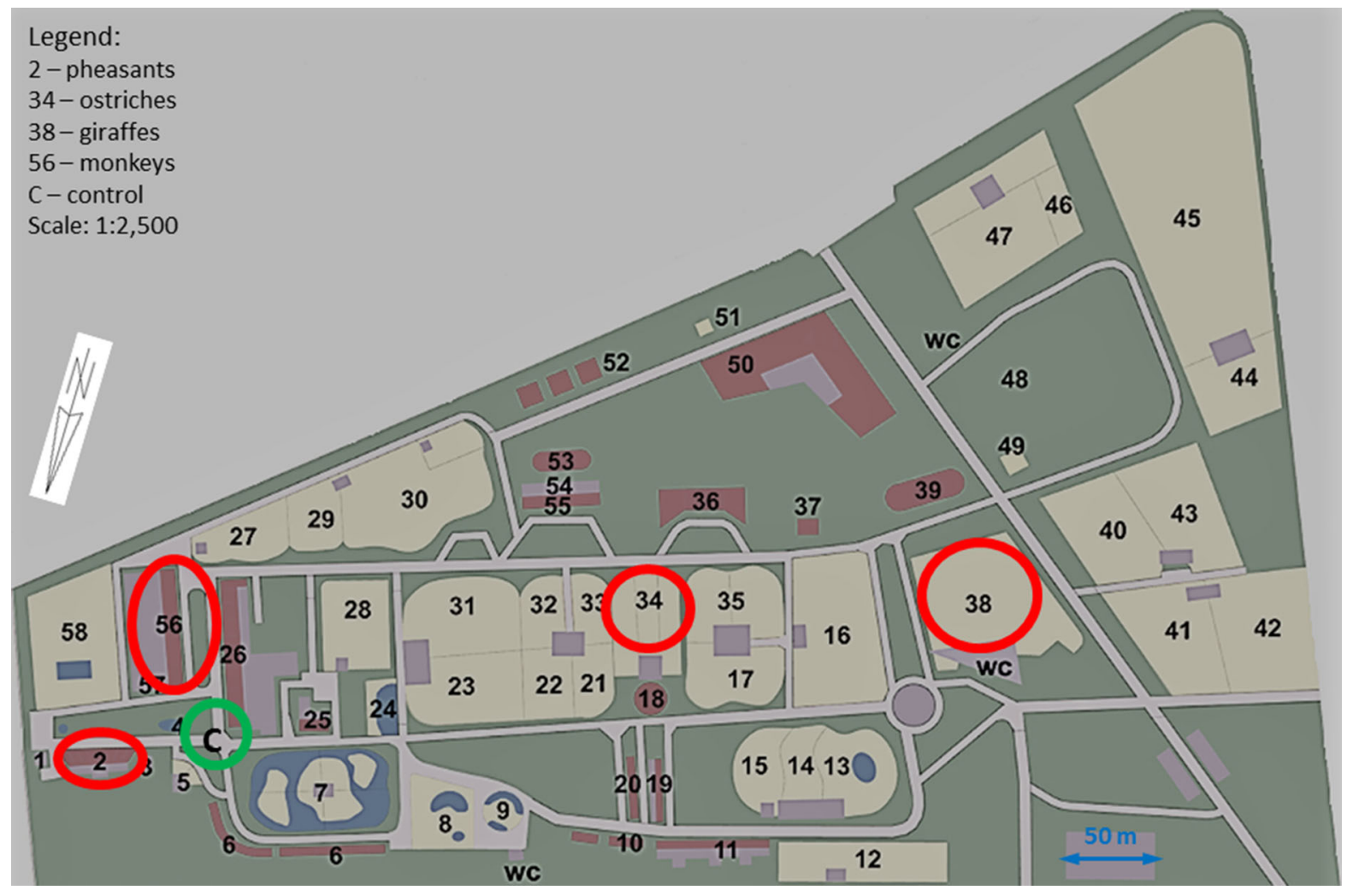

Fig. 1 Location of the sampling sites

samples were incubated at $37{ }^{\circ} \mathrm{C}$ in aerobic conditions for $48 \mathrm{~h}$. After incubation time, the colonies characteristic of each group of analyzed bacteria were enumerated according to Jensen and Schafer (1994). Having regard to the fact that direct measurement of concentrations of viable airborne bacteria is difficult, the results were expressed in the form of the commonly used substitute for the concentration of living microorganisms, i.e., as the number of colonyforming units per $\mathrm{m}^{3}$ of air $\left(\mathrm{CFU} / \mathrm{m}^{3}\right)$.

Dust concentration was measured using a DustTrak $^{\mathrm{TM}}$ II Aerosol Monitor 8530 (TSI Inc., USA) laser photometer. The device allows to measure four fractions of dust: $\mathrm{PM}_{10}$ (i.e., dust particles not larger than $10 \mu \mathrm{m}$ ), $\mathrm{PM}_{4}, \mathrm{PM}_{2.5}$ and $\mathrm{PM}_{1}$ (dust particles with diameters below 4, 2.5 and $1 \mu \mathrm{m}$, respectively), using interchangeable heads. The sampling time for each dust fraction was $1 \mathrm{~min}$.

Microclimatic parameters (temperature and relative humidity) were measured using the Kestrel 4000 Weather Meter (Nielsen-Kellerman, USA).
A number of quality control procedures were used in the study. An adequate number of culture media, plates and replicates were used for each series of measurements, following the recommendations of the Polish Standard PN-EN 12322 (2005). Sterility of the media was ensured by incubating the plates with the media at appropriate temperature for 3 days (ISO 11,133 2014). Blank plates were used in each series of measurements, and they were incubated at the temperature used for the remaining plates. The measurement devices (Andersen impactor, DustTrak Aerosol Monitor and Kestrel Weather Meter), as well as all laboratory equipment used in our study are regularly checked and have current certificates.

Aggregates containing microorganisms with aerodynamic diameters below $4.7 \mu \mathrm{m}$ are treated as the respirable fraction of bioaerosol. In the case of dust, it was assumed that the respirable fraction consists of dust particles smaller than $4.0 \mu \mathrm{m}$.

The recorded bioaerosol concentrations, due to the absence of guidelines on the acceptable concentrations of microorganisms in animal rooms, were referred to 
the proposal of the Team of Experts in Biological Factors (pol.: ZECB) (Augustyńska and Pośniak 2016) on the recommended concentrations of airborne microorganisms, treating animal rooms as working premises contaminated with organic dust (Table 2). The observed values were also compared with the proposals for limit values of airborne microorganisms for other countries (Table 3).

Statistical analysis was performed using the Statistica 13 software (StatSoft, USA). The observed values of bacterial aerosol are presented as median values and ranges. The normality of data distribution was tested using the Shapiro-Wilk test. The distribution of total and respirable fraction values was close to normal, and other data were not normally distributed; therefore,

Table 2 Proposals for acceptable concentrations of airborne microorganisms in the working environment according to the Team of Experts in Biological Factors (ZECB) - the values applicable in Poland

\begin{tabular}{ll}
\hline Microbiological agent & $\begin{array}{l}\text { Acceptable concentration } \\
\left(\mathrm{CFU} / \mathrm{m}^{3}\right)^{*}\end{array}$ \\
\hline Mesophilic bacteria & 100,000 \\
Gram-negative bacteria & 20,000 \\
\hline
\end{tabular}

*The recommended values should be twice lower for respirable fraction (RF), i.e., $50,000 \mathrm{CFU} / \mathrm{m}^{3}$ for mesophilic bacteria and $10,000 \mathrm{CFU} / \mathrm{m}^{3}$ for Gram-negative bacteria both parametric (one-way ANOVA, followed by post hoc Tukey's test) and nonparametric (Kruskal-Wallis test) tests were applied to assess the significance of differences between the concentrations of bioaerosols in enclosures for different animals. Spearman's and Pearson's correlation coefficients were applied to assess whether there are statistically significant relations between the concentrations of bacteriological aerosol components and other analyzed parameters of air (temperature, relative humidity and particulate matter concentration) in the tested sites.

\section{Results and discussion}

Table 4 presents the median values and ranges of bacterial aerosol concentrations in enclosures for different groups of animals in the analyzed zoological garden. The median values of the total number of bacteria ranged from $821 \mathrm{CFU} / \mathrm{m}^{3}$ (pheasants) to $6880 \mathrm{CFU} / \mathrm{m}^{3}$ (monkeys), for mannitol-positive staphylococci these values ranged from 212 (giraffes) to $23,011 \mathrm{CFU} / \mathrm{m}^{3}$ (ostriches), for mannitol-negative staphylococci the range was from 391 (monkeys) to $1333 \mathrm{CFU} / \mathrm{m}^{3}$ (giraffes), while in the case of Gramnegative bacteria the range was within 0 (ostriches) to $155 \mathrm{CFU} / \mathrm{m}^{3}$ (pheasants). The largest median values of respirable fraction (RF) were observed as follows: The number of mesophilic bacteria was $5771 \mathrm{CFU} /$

Table 3 Proposals for acceptable concentrations of airborne microorganisms in other countries (after Górny et al. 2011)

\begin{tabular}{|c|c|c|}
\hline $\begin{array}{l}\text { Microbiological } \\
\text { agent }\end{array}$ & $\begin{array}{l}\text { Organization or country or individual proposals (year } \\
\text { of publishing) }\end{array}$ & Acceptable concentration $\left[\mathrm{CFU} / \mathrm{m}^{3}\right] /$ environment \\
\hline $\begin{array}{l}\text { Total number of } \\
\text { bacteria }\end{array}$ & $\begin{array}{l}\text { CEC (commission of the European Communities) } \\
\text { (1993) }\end{array}$ & $\begin{array}{l}<50 \text { (very low contamination) } \\
<100 \text { (low contamination) } \\
<500 \text { (average contamination) } \\
<2000 \text { (high contamination) } \\
>2000 \text { (very high contamination)/all values for non- } \\
\text { industrial rooms }\end{array}$ \\
\hline $\begin{array}{l}\text { Total number of } \\
\text { bacteria }\end{array}$ & China: Ministry of Health (2001) & $<2500 /$ residential premises \\
\hline $\begin{array}{l}\text { Total number of } \\
\text { bacteria }\end{array}$ & Nevalainen (1989) & 4500/dwellings \\
\hline $\begin{array}{l}\text { Total number of } \\
\text { bacteria }\end{array}$ & Reponen et al. (1990) & 5000/dwellings \\
\hline $\begin{array}{l}\text { Sum of bacteria and } \\
\text { fungi }\end{array}$ & Donham (1991) & 430,000/animal confinement buildings \\
\hline
\end{tabular}




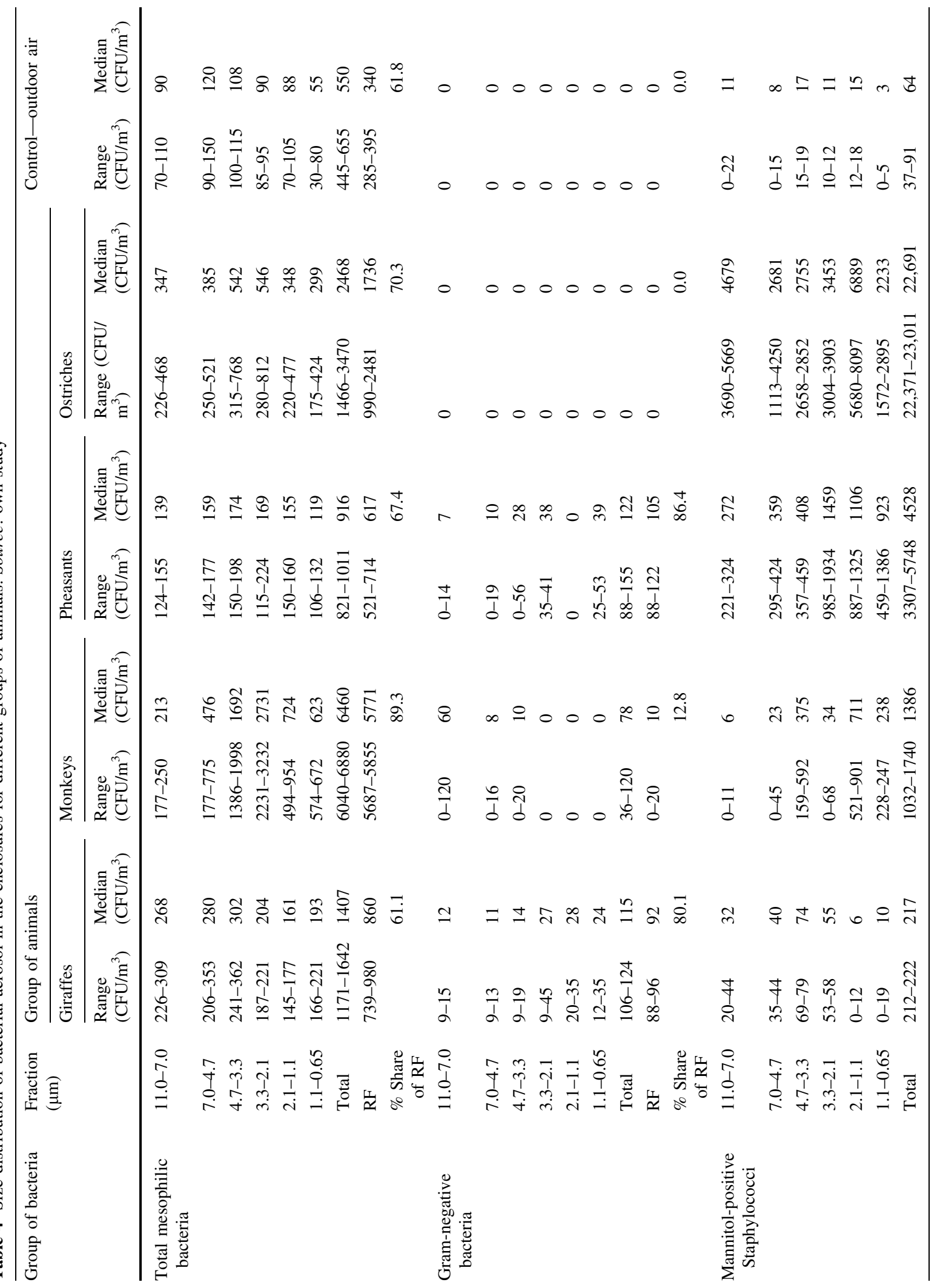




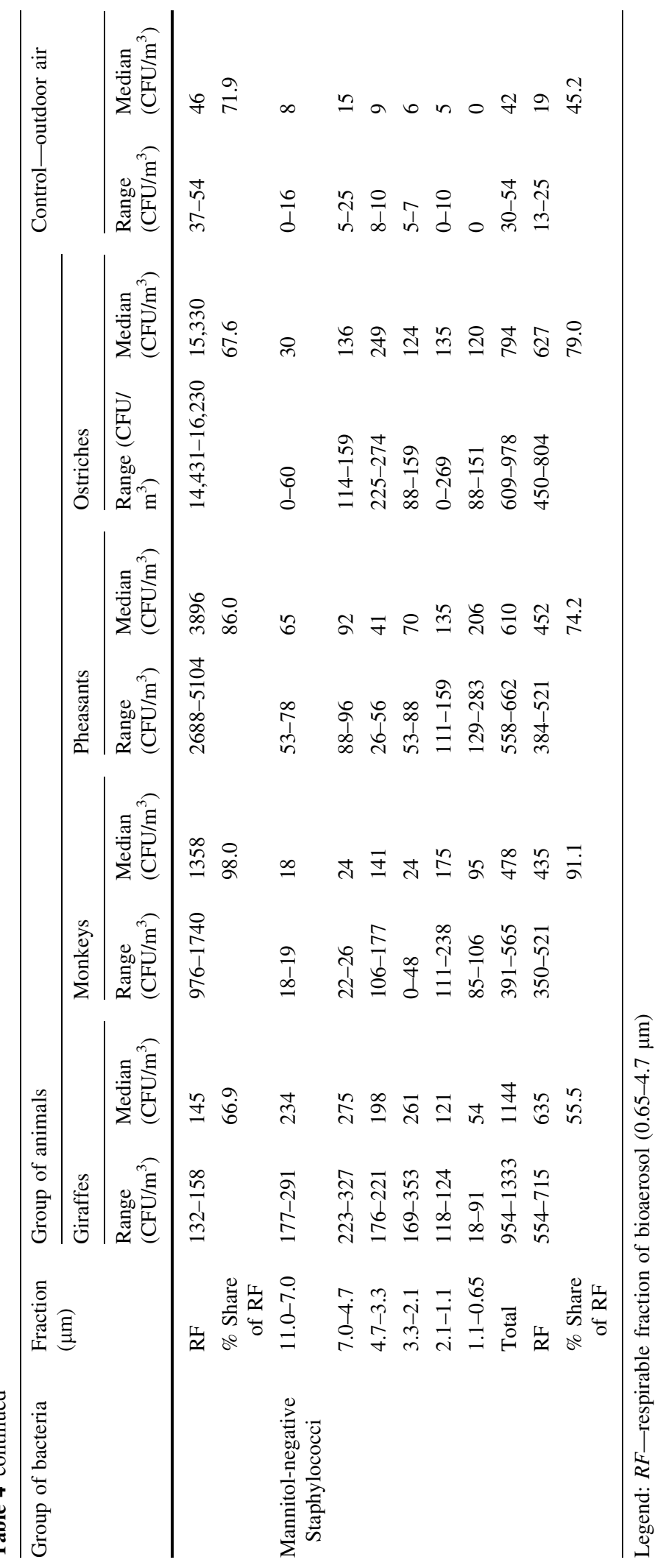


Fig. 2 Mean concentration of the total fraction of bioaerosol in rooms for the studied animals juxtaposed with the concentration of particulate matter- $-\mathrm{PM}_{10}$. Explanations of the symbols used in Figs. 2 and 3: Ppheasants, $\mathrm{M}$-monkeys, $\mathrm{O}$-ostriches, $\mathrm{G}$ - giraffes; TB-total mesophilic bacteria, SM- -mannitolnegative staphylococci, $\mathrm{SM}+-$ mannitol-positive staphylococci, GnegGram-negative bacteria

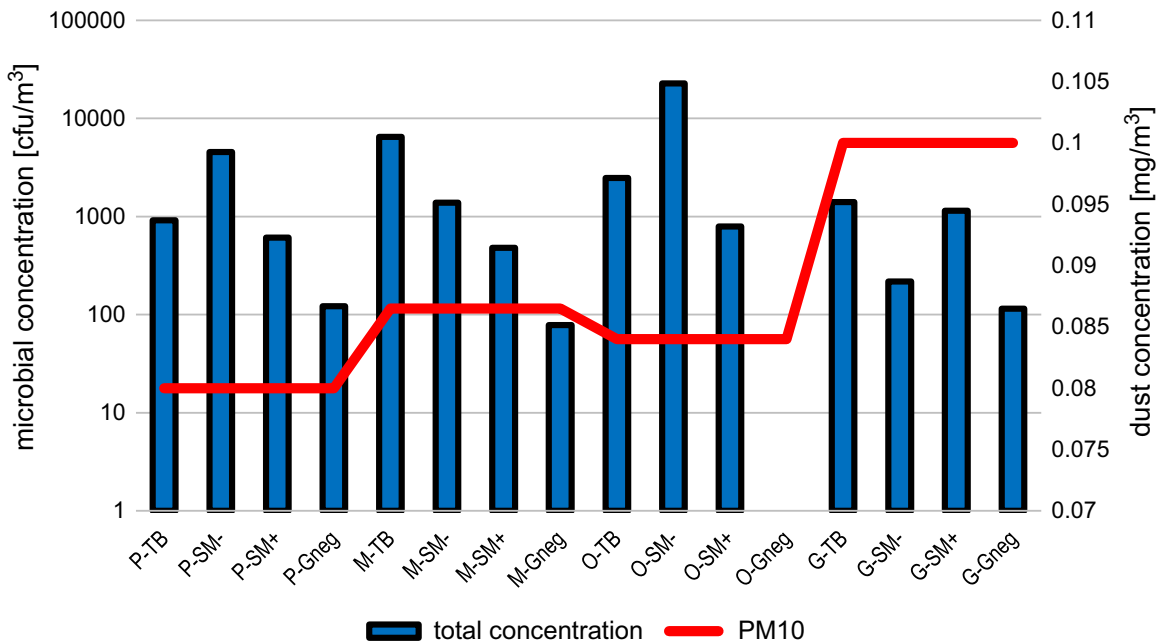

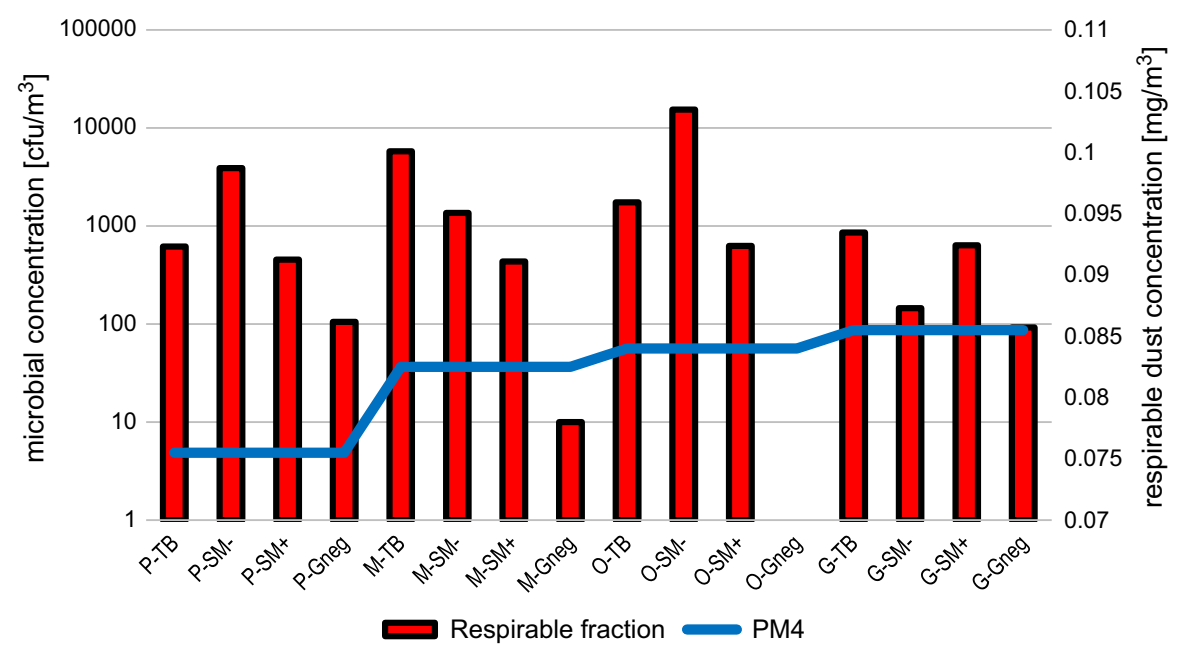

Fig. 3 Mean concentration of the respirable fraction of bioaerosol in rooms for the studied animals juxtaposed with the concentration of particulate matter- $-\mathrm{PM}_{4}$. Explanations of the symbols used are given in the caption of Fig. 2

$\mathrm{m}^{3}$-in enclosures for monkeys, mannitol-positive staphylococci-in rooms for ostriches $(15,330 \mathrm{CFU} /$ $\left.\mathrm{m}^{3}\right)$, mannitol-negative staphylococci-for giraffes $\left(635 \mathrm{CFU} / \mathrm{m}^{3}\right)$ and Gram-negative bacteria-also for giraffes $\left(92 \mathrm{CFU} / \mathrm{m}^{3}\right)$. It can be noticed that the concentration of the respirable fraction (RF) and total concentration (TC) of bacterial aerosol varies between enclosures for different animals, both between the analyzed species of mammals and the species of birds, as shown in Figs. 2 and 3. The one-way ANOVA test showed that the differences in values of bacterial aerosol between animals are statistically significant
( $F=21.52$ for the total fraction and $F=11.85$ for the respirable fraction, $p<0.05)$. Tukey's test specified that for the total fraction, the differences were significant in the case of mesophilic bacteria and mannitol-positive Staphylococcus, while for the respirable fraction, the statistically significant differences were obtained for bacteria, mannitol-positive staphylococci and Gram-negative bacteria. Detailed results of the statistical test are given in Table 5. It can be noticed that there are more statistically significant differences in the bioaerosol concentration between the premises for monkeys and ostriches and those in 
Table 5 Results of Tukey's test showing the significance of differences in the concentration of bacterial components of bioaerosol between various groups of animals. Only significant values are shown $(p<0.05)$

\begin{tabular}{|c|c|c|c|c|c|c|}
\hline \multirow[t]{2}{*}{ Fraction of bioaerosol } & \multirow[t]{2}{*}{ Group of bacteria } & \multicolumn{5}{|c|}{ Animals tested } \\
\hline & & & Giraffes & Monkeys & Pheasants & Ostriches \\
\hline \multirow[t]{8}{*}{ Total fraction } & \multirow[t]{4}{*}{ Bacteria } & Giraffes & - & 0.01 & - & - \\
\hline & & Monkeys & 0.01 & - & 0.008 & 0.024 \\
\hline & & Pheasants & - & 0.008 & - & - \\
\hline & & Ostriches & - & 0.024 & - & - \\
\hline & \multirow{4}{*}{ Mannitol-positive Staphylococcus } & Giraffes & - & - & 0.03 & 0.0003 \\
\hline & & Monkeys & - & - & - & 0.0003 \\
\hline & & Pheasants & 0.03 & - & - & 0.0004 \\
\hline & & Ostriches & 0.0003 & 0.0003 & 0.0004 & - \\
\hline \multirow[t]{12}{*}{ Respirable fraction } & \multirow[t]{4}{*}{ Bacteria } & Giraffes & - & 0.003 & - & - \\
\hline & & Monkeys & 0.003 & - & 0.002 & 0.006 \\
\hline & & Pheasants & - & 0.002 & - & - \\
\hline & & Ostriches & - & 0.006 & - & - \\
\hline & \multirow[t]{4}{*}{ Mannitol-positive Staphylococcus } & Giraffes & - & - & - & 0.0008 \\
\hline & & Monkeys & - & - & - & 0.0009 \\
\hline & & Pheasants & - & - & - & 0.002 \\
\hline & & Ostriches & 0.0008 & 0.0009 & 0.002 & - \\
\hline & \multirow[t]{4}{*}{ Gram-negative bacteria } & Giraffes & - & 0.015 & - & 0.009 \\
\hline & & Monkeys & 0.015 & - & 0.009 & - \\
\hline & & Pheasants & - & 0.009 & - & 0.006 \\
\hline & & Ostriches & 0.009 & - & 0.006 & - \\
\hline
\end{tabular}

rooms for other animals than in the case of giraffes and pheasants.

What can also be easily observed is that the concentrations of bacterial aerosol inside the examined premises were much higher than those observed in the outdoor air (Table 4). For instance, the number of total mesophilic bacteria was from 1.6 times higher (enclosures for pheasants) to even almost 12 times higher (in rooms for monkeys) than the one observed outdoors. The numbers of mannitol-negative staphylococci were from 11.4 (monkeys) to 27.2 (giraffes) greater than those observed outdoors, while in the case of mannitol-positive staphylococci these values ranged from 3.4 (giraffes) to even 354 times (enclosures for ostriches). The ratios observed in our study are much larger than those observed by, e.g., Brạgoszewska et al. (2018a) in their study conducted in different types of workplaces, i.e., an office building, where the maximum levels of bacterial aerosol indoors were about four times greater than those observed outdoors. On the other hand, Qian et al. (2012) observed that the concentrations of microbial particle mass in an occupied classroom of a university were about ten times higher than those observed in the outdoor air. A number of proposed hygienic standards suggest using the ratio of microbial concentrations measured inside and outside studied facilities in order to determine the admissible contamination (Górny et al. 2016). According to Burge (1990), if the concentration of bioaerosol indoors exceeds $1.0 \times 10^{3} \mathrm{CFU} / \mathrm{m}^{3}$ and persistently exceeds at least twofold the concentration found outdoors, it is necessary to take preventive measures in terms of the indoor air quality. Also, Reponen et al. (1990) suggested that if the indoor/outdoor ratio is much higher than 1 , it confirms the presence of an internal source of microbial emission. The values observed in this study confirm that the presence of animals as well as their feces and litter significantly affects the quality of air in their houses. 
In terms of the most numerous group of microorganisms, the highest median value in our study was observed for mannitol-positive staphylococci-it was recorded in the rooms for ostriches $\left(22,691 \mathrm{CFU} / \mathrm{m}^{3}\right.$ of air), with the highest share of the fine fraction (2.1-1.1 $\mu \mathrm{m}$ accounting for $30.3 \%)$. Mannitol-positive staphylococci were the predominant group of microorganisms in the case of birds; however, in the case of mammals (giraffes and monkeys), their concentrations were from three (as compared between monkeys and pheasants) to more than a hundred times lower (as compared between giraffes and ostriches) than in the air of bird enclosures. This could be explained by the fact that staphylococci are among the components of natural microflora of skin, feathers, hair and mucous membranes, so their high concentrations in animal rooms should not be surprising. Differences in the concentrations of various components of microbial aerosol in animal rooms were observed by many authors (Millner 2009; Zhao et al. 2014). For instance, Zhao et al. (2014) suggested that the factors that affect the observed differences in the microbial aerosol concentrations between various animal houses are numerous and always inter-correlated. These factors include animals themselves, their activity, housing system and management, whereas the animal activity can be influenced by the animal age, weight and light schedule. The animal-related factor can be further detailed into age, weight, activity and stocking density. The number of factors is substantial, and discussing all of them is beyond the scope of this study. Nevertheless, the concentration of microbial aerosol in animal housing is always reported to be higher than in the ambient air (Zhao et al. 2014).

Even though the recorded concentrations of bacterial components of bioaerosol were in some cases quite high, after referring the obtained results to the Polish proposals of acceptable concentrations in working environments, provided by ZECB (Augustyńska and Pośniak 2016), it should be considered that the acceptable concentrations were not exceeded in the examined premises. The suggested limit values were developed as a result of volumetric measurements of environmental bioaerosols, suggesting the potential harmfulness of the given groups of microorganisms. Based on these values, it can be concluded that the concentrations of total mesophilic bacteria and Gram-negative bacteria do not pose health threats to the exposed workers of the Kraków Zoo. However, comparing the values observed in our study with the limits suggested by the Commission of the European Communities (1993, Table 3) indicates that in terms of the total numbers of bacteria, the air in all examined premises should be considered as contaminated, while the air in rooms for monkeys and enclosures for ostriches should be considered as even highly contaminated. Considering the lack of international guidelines on the occupational exposure to the bioaerosol concentrations, the results obtained in our study were also compared to the limit values suggested for residential buildings. For instance, the Ministry of Health in China (2001) suggested that the total number of airborne bacteria should not exceed 2500 in residential premises. Nevalainen (1989) proposed that the limit value for dwellings should be 4500 , while according to Reponen et al. (1990) it should be 5000 . All these values were exceeded only in the case of the monkeys' house (median of 6460; Table 4).

Despite the fact that zoological gardens are among the most popular tourist objects, with large number of visitors and workers being potentially exposed to bioaerosols, the literature almost lacks reports on the microbial and dust contamination of air in these places. Due to the nature of rooms for animals in the zoo, which do not have such a dense stocking of animals as piggeries, stables or cowsheds, these buildings could possibly be compared with residential buildings on animal farms. Lis et al. (2008), when conducting research on such buildings in farmhouses, observed the total concentrations of bacteria within the range of 587-9752 CFU $/ \mathrm{m}^{3}$, and for the respirable fraction the range was $325-4176 \mathrm{CFU} / \mathrm{m}^{3}$. In the present studies, the concentration in animal rooms in the zoo was $821-6880 \mathrm{CFU} / \mathrm{m}^{3}$ and $521-5855 \mathrm{CFU} /$ $\mathrm{m}^{3}$, for TC and RF, respectively. Thus, they were similar to those recorded by Lis et al. (2008). One of the few studies concerning the bioaerosol concentration in zoological gardens was that carried out by Tombarkiewicz et al. (2008), who-while conducting research at the monkeys' house of the Kraków Zoorecorded bacterial concentrations ranging from 173 to $1595 \mathrm{CFU} / \mathrm{m}^{3}$ and staphylococci-from 67 to $2275 \mathrm{CFU} / \mathrm{m}^{3}$, but they did not find Gram-negative bacteria. When comparing these results with our study, for monkey rooms the minimum concentrations of bacteria were 34 times higher, but the maximum concentration was approximately twice higher; the range of staphylococcal concentrations 
(391-1740 CFU/ $\mathrm{m}^{3}$ ) was narrower and Gram-negative bacteria were in our case observed (maximum value of $120 \mathrm{CFU} / \mathrm{m}^{3}$ ). This resulted from the fact that Tombarkiewicz et al. (2008) conducted their studies using MAS-100 air sampler, which is much less precise when compared to the six-stage Andersen impactor. The device used in our study allows to assess the particle size distribution of microbial aerosol and to precisely determine the concentration of microorganisms from six different aerodynamic diameters. On this basis, it can be assumed what fraction of the aerosol deposits in individual parts of the respiratory tract, providing much more detailed insight into the characteristics of the studied environment.

While considering the size distribution of bioaerosol fractions for all microorganisms and animals tested, it was found that there are significant differences between rooms for various animals (Fig. 4). Bioaerosol fraction of $3.3-2.1 \mu \mathrm{m}$ had the largest share-i.e., from 15.9 to $33.2 \%$-depending on the group of animals, and the smallest share was observed for the fractions $11-7 \mu \mathrm{m}$ and $7-4.7 \mu \mathrm{m}$. When assessing the percentage of respirable fraction in relation to the total bioaerosol concentration, its highest share was found in rooms for monkeys in the case of three groups of microorganisms: mesophilic bacteria (89.3\%), mannitol-positive staphylococci (98.0\%) and mannitol-negative staphylococci $(91.1 \%)$. The smallest share of respirable fraction was recorded also in rooms for monkeys, but for Gram-negative bacteria (12.8\%). The mean share of respirable fraction in the concentration of all analyzed groups of microorganisms was approximately $68.0 \%$. The observed values are not very different from those reported by, e.g., Chien et al. (2011) in their study conducted on microbial aerosols released from chicken and swine feces, who observed that the proportion of respirable fraction of bacteria ranged from 83.5 to $88.0 \%$. On the other hand, Lis et al. (2008) in their study conducted on farmhouses observed that the share of RF of bacteria ranged from 38 to $80 \%$ with the mean value of $55 \%$. The results obtained by Brạgoszewska et al. (2018b) in their study conducted in educational buildings (preschool, primary school and high school) showed that the contribution of respirable particles ranged from $73 \%$ in a preschool to $84 \%$ in high school, which are rather high shares. As given in Table 4, the share of RF of bioaerosol is in most cases higher in the animal houses than in the outdoor air. Braggoszewska et al. (2018a), who obtained similar results in their study conducted in office buildings, explained this phenomenon by the fact that in the outdoor air the particle size distribution is influenced by two opposing mechanisms. These are the rapid growth of bacterial particles and relatively higher mortality of fine particles, being normally isolated bacterial cells. Also, the proportions of RF observed in our study are large, particularly taking into consideration the fact that the particle size of microbial aerosols determines their penetrability to the human respiratory system. The harmfulness of particles below $5 \mu \mathrm{m}$ (accounting for the respirable
Fig. 4 Percentage share of various bioaerosol fractions in enclosures for different groups of animals

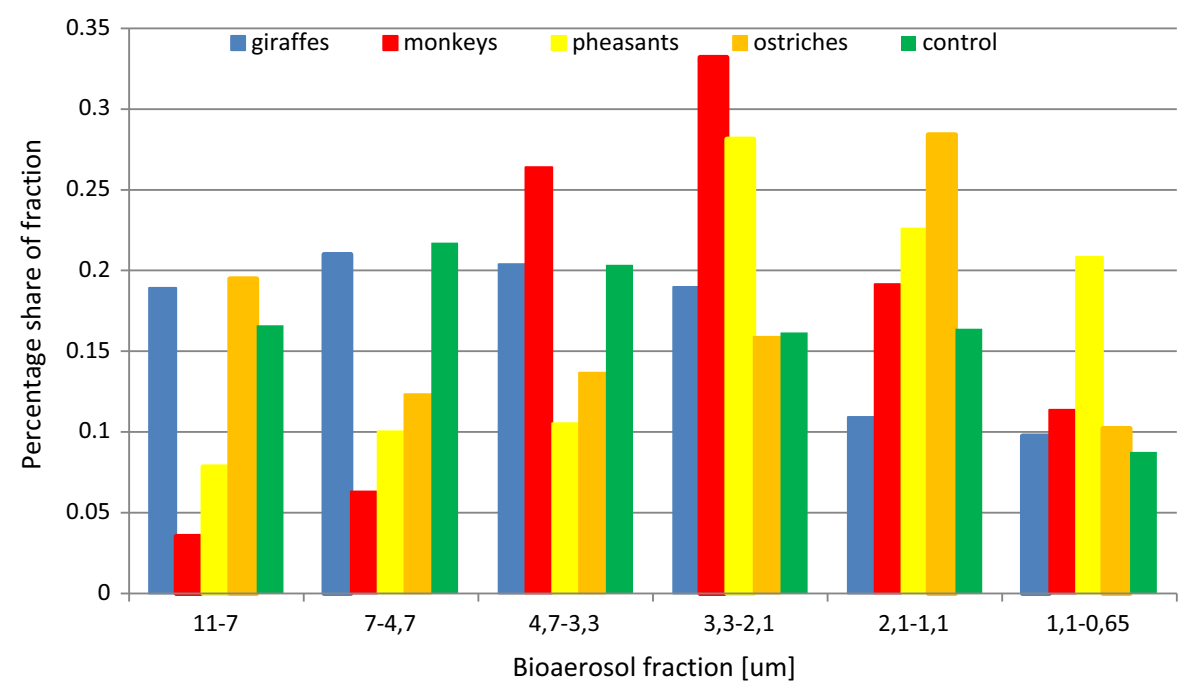


fraction of bioaerosol) is higher than the larger ones, as they reach the alveoli via the trachea and bronchi, causing allergenic and toxic effect (Owen et al. 1992). As suggested by Bragoszewska et al. (2018b), the share of RF reaching $80 \%$ should be treated as a potentially harmful level to the people exposed.

Another factor that might affect the level of bioaerosol inside buildings is their age. Similar studies were conducted by Pasanen et al. (1991) in rural houses in Finland, where they observed that the concentrations of bacterial aerosols were lower in new farmhouses (from 320 to $1850 \mathrm{CFU} / \mathrm{m}^{3}$; geometric mean of $730 \mathrm{CFU} / \mathrm{m}^{3}$ ) than in old ones (from 490 to $4530 \mathrm{CFU} / \mathrm{m}^{3}$; geometric mean of $1930 \mathrm{CFU} / \mathrm{m}^{3}$ ). This is consistent with the results obtained in our study, where the levels of mesophilic bacteria were five times lower in new rooms for giraffes (three years old) than in the older ones for monkeys (ten years old). However, the lowest levels of mannitol-positive staphylococci were recorded in the rooms for giraffes, which were new. Lee et al. (2006) studied indoor bioaerosol levels in urban homes, finding an insignificant variation in the concentration of fungal spores among houses and their parameters, including age. They suggested that some other factors, such as the number of residents and their activity or the building ventilation, may have more significant impact on the bioaerosol concentrations.

The dust concentration in animal premises (Table 6) was only slightly variable. The median of the highest dust concentration in enclosures for giraffes for the $\mathrm{PM}_{10}$ fraction was $0.1 \mathrm{mg} / \mathrm{m}^{3}$, while the lowest values were recorded in enclosures for monkeys and pheasants for the $\mathrm{PM}_{1}$ fraction $\left(0.069 \mathrm{mg} / \mathrm{m}^{3}\right)$. In the premises for all tested animals, the highest concentrations were recorded for the $\mathrm{PM}_{10}$ fraction, intermediate for $\mathrm{PM}_{4}$ and $\mathrm{PM}_{2.5}$, while the lowest for the $\mathrm{PM}_{1}$ fraction. In Poland, there is a standard specifying the maximum average daily concentration for the dust fraction $\mathrm{PM}_{10}$, which is $0.05 \mathrm{mg} / \mathrm{m}^{3}$ (Journal of Laws 2012). This value applies to atmospheric air, but there is no threshold value for indoor air. This means that in the analyzed rooms for animals, this value was exceeded only two times. It should be noted that in Polish cities in the autumn and winter seasons, the level of $\mathrm{PM}_{10}$ in atmospheric air is being significantly and continuously exceeded-sometimes by several times (European Environment Agency 2017; Reizer and Juda-Rezler

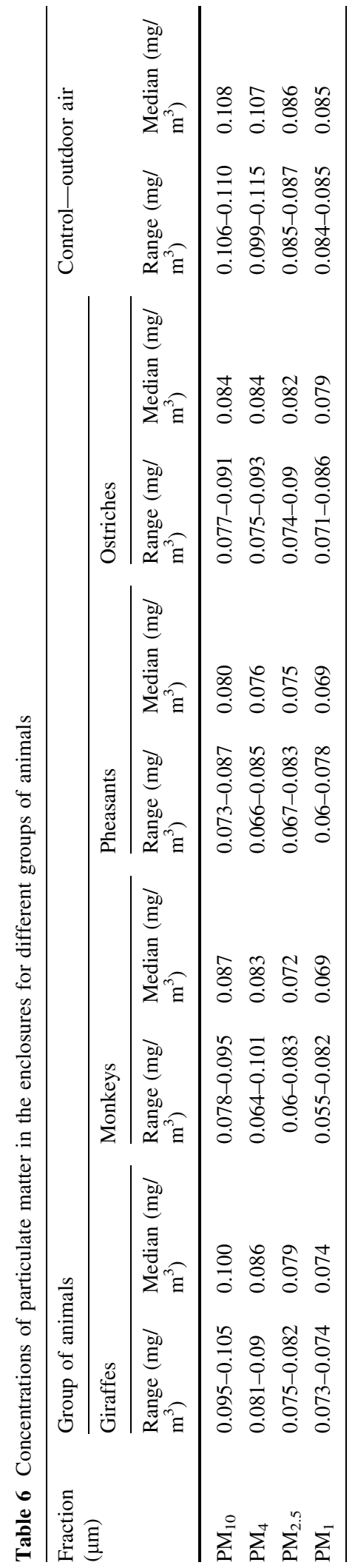


2016). The maximum exposure of workers to harmful biological agents in Poland is defined for inhalable and respirable dust at $2 \mathrm{mg} / \mathrm{m}^{3}$ (Regulation of the Ministry of Family, Labour and Social Policy 2017), and such concentrations were not exceeded in our study. However, what needs to be remembered is that poor indoor air quality, including working environment coupled with exposure to exceeded levels of particulate matter, poses a significant threat to people. In the case of zoos, these are visitors, animal keepers and veterinarians. Because animal environments have higher concentrations of contaminants and greater amount of biological content, the health threats are much higher than those in comparable non-animal environments (Tan and Zhang 2004). Particulate matter in animal rooms is almost entirely biological and organic. It is a mixture of liquid and solid materials, including fodder, hair, urine, feces and microorganisms. Dust particles in animal indoor environments transport biological and organic substances, as well as viruses, bacteria, mold fungi and their spores (Tan and Zhang 2003). Studies of exposure to exceeded concentrations of particulate matter provided evidence that it increases the risk of cardiovascular disease, adverse birth outcomes and neurological and cognitive disorders (Butler and Madhavan 2017). It is very likely that workers transport dust particles on shoes and clothes from animal rooms to residential buildings, consequently posing threat to other people.

In animal rooms, it is possible to measure microclimatic conditions that affect the feeling of warmth, such as temperature, humidity and air movement, but we cannot get to know the "thermal comfort" of animals (Tombarkiewicz et al. 2008). The recommended temperatures for the studied animals range within 16-30 ${ }^{\circ} \mathrm{C}$ (Kołacz and Dobrzański 2006). In this study, the temperature recorded in animal rooms ranged from $17.2{ }^{\circ} \mathrm{C}$ to $27.8^{\circ} \mathrm{C}$ (Table 7); both the lowest and the highest temperatures were recorded in ostrich enclosures. The measured temperatures were within the optimal range for these animals. Moisture in the room air originates from wet floors, walls, food, directly from animal bodies and outdoor air. Too high humidity in animal rooms is undesirable, because it results in increased cooling and at the same time creates favorable conditions for the development of unwanted microflora. The humidity recommended for different groups of animals should be between 50.0 and $80.0 \%$.

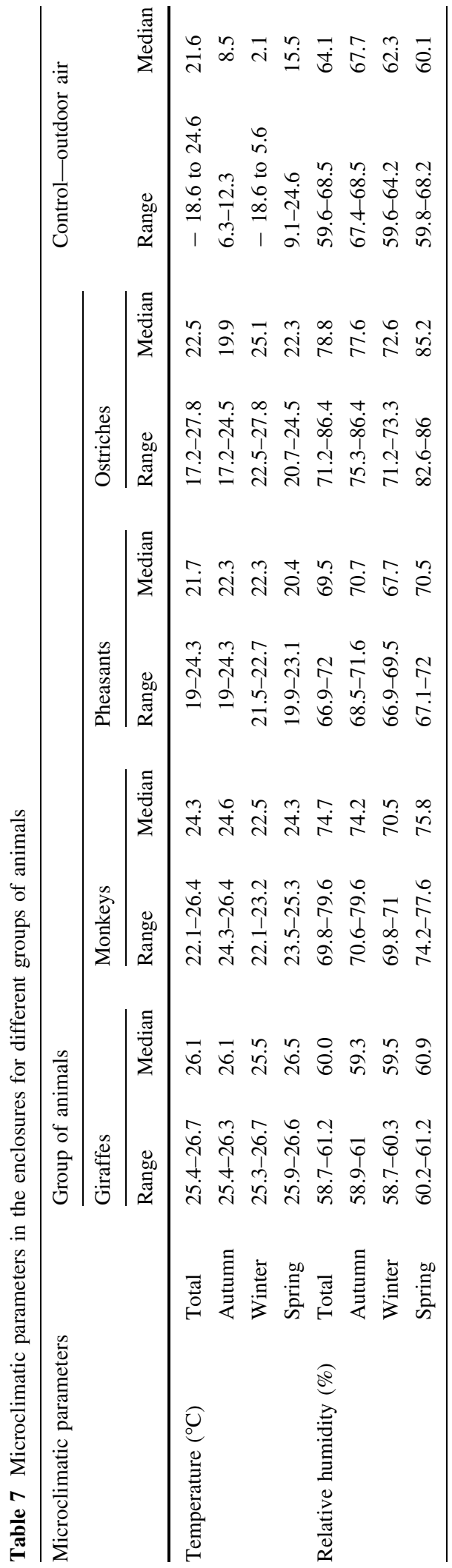


In our study, the most dry air was recorded in the rooms for giraffes (58.7-61.2\%), while the highest humidity was observed in enclosures for ostriches (71.2-86.4\%); regardless of the group of animals, the humidity was within the recommended range (Kołacz and Dobrzański 2006). However, the correlation tests used in our study revealed that there was a statistically significant positive correlation between the relative humidity and concentrations of three fractions of bioaerosol (stages three, four and five), as well as the total and respirable fractions, but the values ( $\mathrm{r}$ value from 0.37 for stage three and total fraction to 0.42 for stage four) indicated that this correlation was weak. No statistically significant relationships were detected between the temperature or the dust concentration in the air and the level of bioaerosols in the examined animal premises. This might result from the fact that all the mentioned parameters inside the tested rooms were not subject to considerable variation, as might be observed outdoors. For instance, Brągoszewska and Pastuszka (2018) in their study on the effect of meteorological factors on the bacterial bioaerosol levels in the outdoor air in Gliwice observed that the air temperature was one of the most important factors shaping the concentrations of viable bacteria. Raisi et al. (2013) observed that in terms of bacterial aerosol, most significant correlations were observed with the ambient temperature (moderate negative correlation). Similarly to the observations made in our study, the bacterial aerosol did not correlate with any of the particulate matter fractions.

\section{Conclusions}

The observations made in our study showed significant differences between the premises for various animals, both in terms of the concentrations of bacterial bioaerosol components and in terms of the predominant groups of bacteria. It could be noticed that monkeys and ostriches were the most outlying groups of animals in terms of the maximum values of total number of mesophilic bacteria and mannitol-positive staphylococci. The observed indoor concentrations of bacterial aerosol relative to the outside air indicate that the animals are a significant source of bacterial components of bioaerosol.

Comparison of the observed concentrations of bacterial aerosol with the Polish guidelines on occupational health shows that the bioaerosol levels observed in our study should not be harmful to the health of the zoo workers or its visitors. However, international regulations suggest that the recorded contamination exceeds the acceptable limits.

Also, the share of respirable fraction of bioaerosol may indicate the possible health threats, as in most groups of bacteria, the respirable fraction was predominant with the mean share being approximately $70 \%$ of the total fraction.

The correlation analysis did not show any significant relationship between the bacterial aerosol levels and the microclimatic parameters of air or the particulate matter fractions. This might be due to the small variability of the mentioned parameters indoors.

In contrast to bioaerosols, the concentrations of dust particles were at very similar, quite low, levels. The workers' exposure to organic dust cannot be considered as potentially harmful.

Having regard to the specificity of the zoological gardens, which are both working environments and very popular tourist objects visited by families with small children, attention should be paid to thorough cleaning of animals and their premises, as well as to maintaining appropriate levels of microclimatic parameters prevailing in the rooms. Further and more detailed studies are needed to determine the species composition of the microbial aerosol, to assess the possible threat to the health of workers and visitors related to the exposure to pathogenic, potentially pathogenic or allergenic microorganisms.

Acknowledgements This study was funded by the statutory measures of the University of Agriculture-Grant No. DS $3158 / \mathrm{KM} / 2016$.

Open Access This article is distributed under the terms of the Creative Commons Attribution 4.0 International License (http:// creativecommons.org/licenses/by/4.0/), which permits unrestricted use, distribution, and reproduction in any medium, provided you give appropriate credit to the original author(s) and the source, provide a link to the Creative Commons license, and indicate if changes were made.

\section{References}

Augustyńska, D.\& Pośniak, M. (eds.) (2016). Harmful factors in the working environment-Limit values. Interdepartmental Commission for Maximum Admissible Concentrations and Intensities for Agents Harmful to Health in the Working Environment: CIOP-PIB (in Polish). 
Brągoszewka, E., Biedroń, I., Kozielska, B., \& Pastuszka, J. S. (2018). Microbiological indoor air quality in an office building in Gliwice, Poland: analysis of the case study. Air Quality, Atmosphere and Health, 11, 729-740.

Brągoszewska, E., Mainka, A., Pastuszka, J., Lizończyk, K., \& Desta, Y. G. (2018). Assessment of bacterial aerosol in a preschool, primary school and high school in Poland. Atmosphere, 9, 87. https://doi.org/10.3390/atmos9030087.

Brągoszewska, E., \& Pastuszka, J. S. (2018). Influence of meteorological factors on the level and characteristics of culturable bacteria in the air in Gliwice, Upper Silesia (Poland). Aerobiologia, 34, 241-255.

Burge, H. A. (1990). Bioaerosols: Prevalence and health effects in the indoor environment. Journal of Allergy and Clinical Immunology, 86, 687-701.

Butler, D. A., \& Madhavan, A. (2017). Communicating the health effects of indoor exposure to particulate matter. Indoor Air, 27(3), 503-505.

CEC_Commission of the European Communities. (1993). Indoor air quality \& its impact on man: Report No. 12: Biological particles in indoor environments. BrusselsLuxembourg: ECSC-EEC-EAEC.

Chien, Y.-C., Chen, C.-J., Lin, T.-H., Chen, S.-H., \& Chien, Y.C. (2011). Characteristics of microbial aerosols released from chicken and swine feces. Journal of the Air and Waste Management Association, 61(8), 882-889.

D’Arcy, N., Canales, M., \& Spratt, D. A. (2012). Healthy schools: Standardisation of culturing methods for seeking airborne pathogens in bioaerosols emitted from human sources. Aerobiologia (Bologna), 2012(28), 413-422.

Donham, K. J. (1991). Association of environmental air contaminants with disease and productivity in swine. American Journal of Veterinary Research, 52, 1723-1730.

Douglas, P., Robertson, S., Gay, R., Hansell, A. L., \& Gant, T. W. (2018). A systematic review of the public health risks of bioaerosols from intensive farming. International Journal of Hygiene and Environmental Health, 221(2), 134-173.

Douwes, J., Thorne, P., Pearce, N., \& Heederik, D. (2003). Bioaerosol health effects and exposure assessment: progress and prospects. Annals of Occupational Hygiene, 47, 187-200.

EAZA Standards for the Accommodation and Care of Animals in Zoos and Aquaria, European Association of Zoos and Aquaria, 27 September 2014.

European Environment Agency: Air quality in Europe-2017 report, Publications Office of the European Union (2015), ISSN: 1977-8449.

Górny, R. L., Cyprowski, M., Ławniczek-Wałczyk, A., GołofitSzymczak, M., \& Zapór, L. (2011). Biohazards in the indoor environment-A role for threshold limit values in exposure assessment. In M. R. Dudzińska (Ed.), The Management of indoor air quality (pp. 1-20). London: CRC Press.

Górny, R. L., Harkawy, A. S., Ławniczek-Wałczyk, A., Karbowska-Berent, J., Wlazło, A., Niesler, A., et al. (2016). Exposure to culturable and total microbiota in cultural heritage conservation laboratories. International Journal of Occupational Medicine and Environmental Health, 29(20), 255-275.
ISO 11133:2014. (2014). Microbiology of food, animal feed and water-Preparation, production, storage and performance testing of culture media.

Jensen, P. A., \& Schafer, M. P. (1994). Sampling and characterization of bioaerosols. In P. M. Eller \& M. E. Cassinelli (Eds.), NIOSH manual of analytical methods (4th ed., pp. 82-112). Cincinatti: Centers for Disease Control and Prevention.

Kaliste, E., Linnainmaa, M., Meklin, T., \& Nevalainen, A. (2002). Airborne contaminants in conventional laboratory rabbit rooms. Laboratory Animals, 36(1), 43-50.

Kołacz, R., \& Bodak, E. (1999). Animal welfare and the criteria for its evaluation. Veterinary Medicine-Science and Practice, 3, 147-154. (in Polish).

Kołacz, R., \& Dobrzański, Z. (2006). Hygiene and welfare of livestock animals. New Delhi: AR Wrocław Publishing House. (in Polish).

Kruszewicz, A. G. (2011). The role of zoos in saving endangered species and improving the welfare of non-domestic animals. Animal Production Review, 11, 8-9. (in Polish).

Lee, T., Grinshpun, S. A., Martuzevicius, D., Adhikari, A., Crawford, C. M., Luo, J., et al. (2006). Relationship between indoor and outdoor bioaerosols collected with a button inhalable aerosol sampler in urban homes. Indoor Air, 16(1), 37-47.

Lis, D. O., Mainelis, G., \& Górny, R. O. (2008). Microbial air contamination in farmhouses-quantitative aspects. CLEAN-Soil Air Water, 36(7), 551-555.

Lorenz, H. (2004). Bioaerosols in university animal care facilities. Theses and Dissertations. 1520. The University of Toledo. Medical Collego of Ohio.

Matković, K., Vučemilo, M., Vinković, B., Šeol, B., Pavičić, Ž., \& Matković, S. (2007). Qualitative structure of airborne bacteria and fungi in dairy barn and nearby environment. Czech Journal of Animal Science, 52(8), 249-254.

Millner, P. D. (2009). Bioaerosols associated with animal production operations. Bioresource Technology, 100, 5379-5385. https://doi.org/10.1016/j.biortech.2009.03. 026.

Nevalainen, A. (1989). Bacterial Aerosols in Indoor Air. PhD thesis. Helsinki: National Public Health Institute.

Owen, M. K., Ensor, D. S., \& Sparks, L. E. (1992). Airborne particle sizes and sources found in indoor air. Atmospheric Environment, 26A(12), 2149-2162.

Pasanen, A. L., Tuomainen, M., Kalliokoski, P. \& Nevalainen, A. (1991). Airborne bacteria and fungi in rural houses in Finland. In Proceedings of IAQ'91 Healthy Buildings, ASHARE, Tullie Circle. p. 142.

PN-EN 12322. (2005). In vitro diagnostic medical devices. Culture media for microbiology. Performance criteria for culture media.

Qian, J., Hospodsky, D., Yamamoto, N., Nazaroff, W. W., \& Peccia, J. (2012). Size-resolved emission rates of airborne bacteria and fungi in an occupied classroom. Indoor Air, 22(4), 339-351.

Raisi, L., Aleksandropoulou, V., Lazaridis, M., \& Katsivela, E. (2013). Size distribution of viable, cultivable, airborne microbes and their relationship to particulate matter concentrations and meteorological conditions in a Mediterranean site. Aerobiologia, 29, 233-248. 
Regulation of the Minister of the Environment of 20 December 2004 regarding the conditions for breeding and maintaining particular groups of animal species in a zoo [Journal of Laws of the Republic of Poland 2004.5.32].

Regulation of the Minister of the Environment of 24 August 2012 on the levels of certain substances in the air [Journal of Laws of the Republic of Poland 2012.1031].

Regulation of the Ministry of Family, Labour and Social Policy of 7 July 2017 on the publication of a uniform text of the Regulation of the Minister of Labor and Social Policy on the highest permissible concentrations and intensities of factors harmful to health in the work environment. Journal of Laws of the Republic of Poland 2017 item 1348.

Reizer, M., \& Juda-Rezler, K. (2016). Explaining the high PM $_{10}$ concentrations observed in Polish urban areas. Air Quality, Atmosphere and Health, 9, 517-531.

Reponen, T., Nevalainen, A., Jantunen, M., Pellikka, M. \&Kalliokoski, P. (1990). Proposal for an upper limit of the normal range of indoor air bacterial and fungal spores in subarctic climate. In Walkinshaw, D. S. (ed.) Indoor Air'90. Proceedings of the 5th International Conference on Indoor Air Quality and Climate (Vol. 2), 29 July-3 August 1990; Toronto, Canada, Ottawa.

Samadi, S., Wouters, I. M., \& Heederik, D. J. J. (2013). A review of bio-aerosol exposures and associated health effects in veterinary practice. Annals of Agricultural and Environmental Medicine, 20(2), 206-221.

Tan, Z., \& Zhang, Y. (2003). An Overview of Particulate Matters in Indoor Environments: Sources and Effects. ASHRAE Transaction, 109(2), 89-100.

Tan, Z., \& Zhang, Y. (2004). A review of effects and control methods of particulate matter in animal indoor environments. Journal of the Air and Waste Management Association, 4(7), 845-854.

Tombarkiewicz, B., Sulińska, M., Grzyb, J., Pawlak, K., \& Niedziółka, J. (2008). Evaluation of sanitary and hygienic conditions in the monkey house of the Krakow Zoological Garden. Ecology and Technology, 16(5A), 182-185.

Yoon, C., Lee, K., \& Park, D. (2011). Indoor air quality differences between urban and rural preschools in Korea. Environmental Science and Pollution Research, 18, 333-345.

Zhao, Y., Aarnink, A. J. A., De Jong, M. C. M., \& Groot Koerkamp, P. W. G. (2014). Airborne microorganisms from livestock production systems and their relation to dust. Critical Reviews in Environmental Science and Technology, 44, 1071-1128.

Zubkowicz, R. (2004). Facts influencing the principles of exhibition organisation within zoological garden. Przyroda $i$ miasto, 8, 289-302. (in Polish). http://zoo-krakow.pl/, Accessed October 92018. 